Boletín de la Sociedad Geológica Mexicana

VOLUMEN 61, NÚM. 2, 2009, P. 239-244

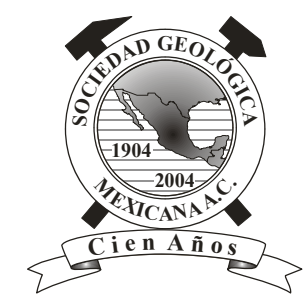

\title{
Preliminary Report on a Late Cretaceous Vertebrate Fossil Assemblage in Northwestern Coahuila, Mexico
}

\author{
Héctor E. Rivera-Sylva ${ }^{1}$, Eberhard Frey², Francisco J. Palomino-Sánchez ${ }^{3}$, José Rubén \\ Guzmán-Gutiérrez ${ }^{4}$, Jorge A. Ortiz-Mendieta ${ }^{5}$ \\ ${ }^{1}$ Departamento de Paleontología, Museo del Desierto. Pról. Pérez Treviño 3745, 25015, Saltillo, Coah., México. \\ ${ }^{2}$ Geowissenschaftliche Abteilung,Staatliches Museum für Naturkunde Karlsruhe. Karlsruhe, Alemania. \\ ${ }^{3}$ Laboratorio de Petrografía y Paleontología, Instituto Nacional de Estadística, Geografía e Informática, Aguascalientes, Ags., México. \\ ${ }^{4}$ Centro para la Conservación del Patrimonio Natural y Cultural de México, Aguascalientes, Ags., México. \\ ${ }^{5}$ Subdirección de Investigación y Colecciones, Museo de Historia Natural y de Cultura Ambiental, México D.F., México. \\ *hrivera@museodeldesierto.org
}

\begin{abstract}
A new vertebrate fossil assemblage of Late Cretaceous age is reported here. This discovery represents the results of the 2007 and 2008 field seasons in the locality known as "Las Jicoteas" situated in the municipality of Ocampo, in northwestern Coahuila, Mexico.

The stratigraphic sequence where this fossil fauna occurs can be correlated to the Lower Member of the continental Aguja Formation that outcrops in the neighbouring Big Bend region of Texas.

This new fauna bears the first record of a nodosaur for Mexico, and, also additional dinosaur remains attributed to the families Tyrannosauridae and Hadrosauridae are recorded. Associated fossil taxa include lepisosteid fishes, turtles and crocodile remains.

The palaeocological conditions inferred by this new faunal assemblage suggest a paralic system with prodelta, marshes, lagoons, and nearshore marine deposits.
\end{abstract}

Keywords: Late Cretaceous, Coahuila, Mexico, Fossil vertebrates, Dinosaurs.

\section{Resumen}

Se reporta aqui el descubrimiento de una nueva asociación faunística de edad Cretácico Tardio, colectada como resultado de las temporadas de campo de 2007 y 2008 en la localidad conocida como "Las Jicoteas", situada en el municipio de Ocampo, al noroeste del estado de Coahuila, México.

La secuencia estratigráfica donde esta fauna fósil aparece puede ser correlacionada con el Miembro Inferior de la Formación Aguja que aflora en la región fronteriza del Big Bend de Texas.

A esta nueva fauna pertenece el primer registro para México de nodosaurio, así como registros de restos de dinosaurio adicionales atribuidos a las familias Tyrannosauridae y Hadrosauridae. Taxa asociados a esta fauna incluyen restos de pejelagarto, tortuga y cocodrilo.

Las condiciones paleoecológicas inferidas por esta nueva asociación faunística sugiere un sistema parálico con un fino prodelta con pantanos, marismas y depósitos marinos costeros.

Palabras clave: Cretácico Tardio, Coahuila, México, Fósiles de vertebrados, dinosaurios. 


\section{Introduction}

All fossil vertebrates described in this paper were recovered from a site located in the municipality of Ocampo, in the western portion of the State of Coahuila, Mexico, near the border limits with the State of Chihuahua. This locality is situated northwest of the town known as El Carricito (Figure 1).

Historically, very few dinosaur remains have been reported from this region of Coahuila, coming from the municipalities of Sierra Mojada and Ocampo (Haarmann, 1913; Janensch, 1926). However, in the past nine years the records on dinosaurs from northwestern Coahuila have increased significantly (Montellano-Ballesteros et al. 2000; Rivera-Sylva and López-Espinosa, 2006; Rivera-Sylva et al. 2006; and Rivera-Sylva et al., 2007).

\subsection{Acronyms}

CPC stands for Colección Paleontológica de Coahuila. The specimens are housed in the palaeontology collections of the Museo del Desierto, Saltillo, Coahuila.

\subsection{Geology}

The geology of Coahuila dinosaur areas has been described based on geological maps (Haarmann, 1913, King, 1940, López-Ramos, 1967). This locality is part of many outcrops formed in the anticlines that constitute the tectonic aspect of the northwestern region of Coahuila. In the lower portion of our outcrop we found bivalves and foraminifers that suggest a correlation with the marine member of the Aguja Formation. In the upper layers within the "Las Jicoteas" where the dinosaurs were found, the beds seem to correspond to the transitional sequence of sandstones, mudstones and limolites, which correlate with the continental sequence of the Aguja Formation. On the other hand, biostratigraphic correlation with marine invertebrates such as Heterohelix sp. proves a Late Campanian age, equivalent to the upper member of the Aguja Formation.

The Aguja Formation comprises mainly irregularly interbedded clay and sandstone horizons, ranging from a few tens of millimetres to more than twelve meters in thickness. Beds of psammitic and psephitic conglomerate, coquina sandstone, carbonaceous clay, lignite, and a rare freshwater limestone appear in parts of the section. The formation is characterized by rapid vertical and lateral facies changes, as well as by a greater proportion of sand that is present in either the overlying or the underlying units (Hopkins, 1965).

Based on the colour of the clay, the formation can be roughly divided into three members. The basal part consists of gray-green clay, which weathers to buff-yellow, and resembles the clays of the underlying Pen Formation. The clay of the central part is green with some buff-yellow beds. In the upper part, the clay shows a melange of pale maroons, greens, blue-blacks, and reds that resemble the clay of the overlying Javelina Formation. The change in clay colour probably reflects a change from open water marine

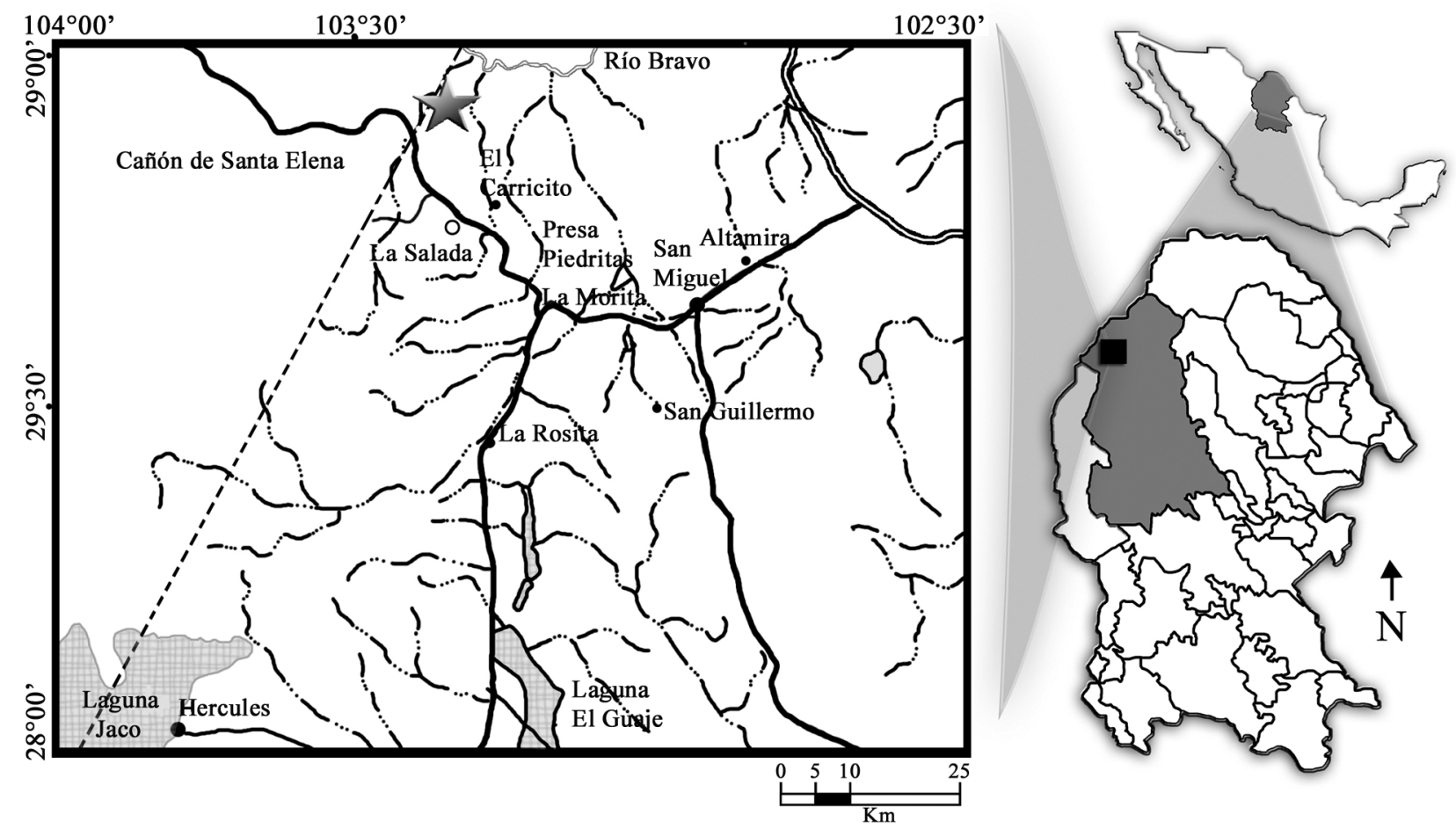

Figure 1. Location map showing the site near El Carricito, indicated with a star 
conditions, through intertidal marine, brackish and fresh water conditions with terrestrial conditions in the middle portion of the formation, where lignites and carbonaceous clay represent the dominant lithology.

Hopkins (1965) recognized oscillating transgressions in the Aguja Formation, with various short termed interchanges of marine and non-marine episodes as the result of local intermittent delta building, and subsequent subsidence due to the compaction of the underlying clays.

The system was deltaic with a narrow prodelta seam with marshes, oxbows, and near shore lagoons with sandy or silty bars (Hopkins, 1965; Lehman, 1982).

\section{Faunal Description}

\subsection{Fishes}

Most of the ganoid scales collected from the locality are fragmentary (CPC-315). The few complete scales recovered show a rhomboid shape; distinct overlapping areas with an articulation process and their massive ganoin layers prove evidence for the presence of large lepisosteids that likely lived upstream. For the time being we assume that the lepisosteids lived and died upstream and their carcasses were washed into the locality after decay or possibly represent digestive elements of predators.

\subsection{Turtles}

The specimens (CPC-316) are 12.36 to $19.98 \mathrm{~mm}$ thick fragments of carapace sculptured with about $0.65 \mathrm{~mm}$ deep pits of round to oval in outline (Fig. 2b). The largest have a diameter of $3.52 \mathrm{~mm}$. The kind of sculpture is diagnostic for Trionychidae, which frequently occur during the Late Cretaceous of North America (Peng et al. 2001). These trionychid carapace fragments are too small for further identification (Estes, 1964; Nicholls, 1972; Gaffney, 1979; Gardner and Russell, 1994; Gardner et al. 1995). However, trionychids, especially large specimens, like those from Las Jicoteas are indicative of extensive, deep, stagnant to low energy limnic to brackish water bodies. The fragmentation of the specimens suggests that the depositional site does not correspond with the place of the death of the animals, and the sharp breaks on the fragments speak for a short transportation distance. The specimen (CPC-317) is a shell fragment (7.25 mm thick) with a smooth surface identify as a Baenidae (Brinkman, pers. comm., 2009).

\subsection{Crocodiles}

Within the reptiles fauna at "Las Jicoteas", a $34.43 \mathrm{~mm}$ fragment of a crocodile tooth (CPC-318) was collected and identified as cf. Deinosuchus (Fig. 2c) based on the massiveness of the specimen (Shwimmer, 2002). Also a small dermal scute (CPC-319) from another crocodilian taxon was found (4.44 mm wide; $20.57 \mathrm{~mm} \mathrm{x} 18.9 \mathrm{~mm}$ ), for the moment this specimen remains undetermined.

\subsection{Dinosaurs}

\subsubsection{Theropods}

CPC-320 is a small $13.48 \mathrm{~mm}$ fragment of a large recurved conical tooth. The serrated mesial and distal carinae are indicative for Theropoda (Figure 3). The denticles at their base measured $0.5 \mathrm{~mm}$ in longitudinal and $0.6 \mathrm{~mm}$ in labiolingual direction. The interdenticular space

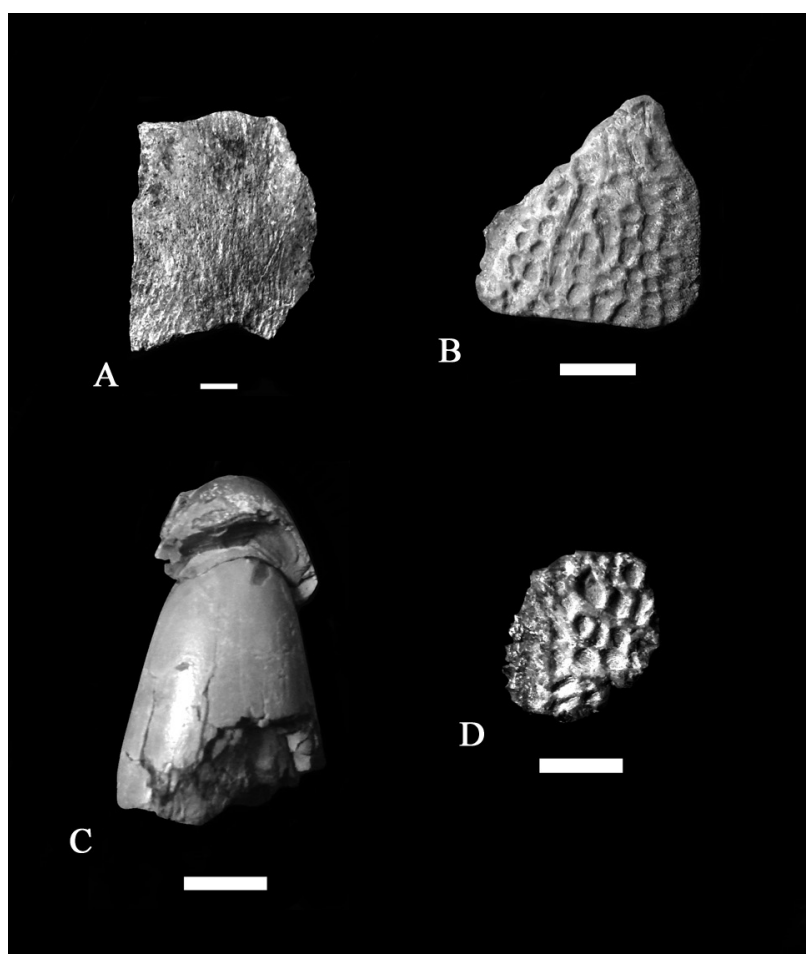

Figure 2. a) Shell fragment of Baenidae, CPC-317; b) carapace fragment of Trionychidae, CPC-316; c) tooth cf. Deinosuchus sp., CPC-318; d) crocodile osteoderm, CPC-319. Scale $=1 \mathrm{~cm}$.

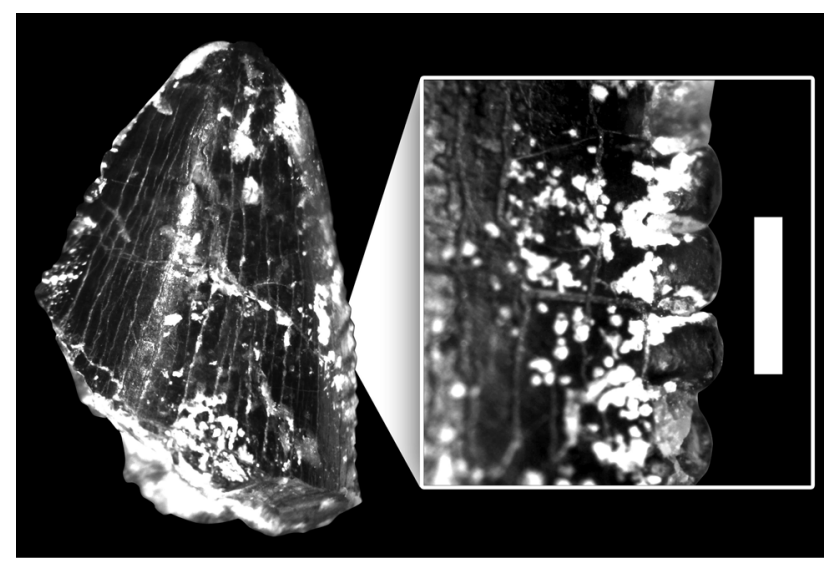

Figure 3. Tyrannosaurid tooth, CPC-320. Scale $=1 \mathrm{~mm}$. 
is $0.2 \mathrm{~mm}$ wide. The serration density is two denticles per $\mathrm{mm}$, which is diagnostic for tyrannosaurids (Farlow and Brinkmann, 1987; Currie et al., 1990; Abler, 1997; Sankey, 2001; Holtz, 2004). This identification is supported by the spatulate shape of the denticles (Sankey, 2001).

Due to the fragmentation of the material, a complete reconstruction could not be done, therefore we cannot say if the specimen was a shed tooth or came from a dead tyrannosaur. Coeval taxa that would fit the morphology of the tooth fragment are Gorgosaurus libratus or Albertosaurus sarcophagus (Currie, 2003).

\subsubsection{Nodosaurs}

The elements discovered from this taxon consist of 15 osteoderms, one spike and several postcranial bone fragments. The material can be attributed to the family Nodosauridae based on three mayor characters:

a) Osteoderms with external cortex with the underlying internal spongiosa much thicker forming a flat base (Scheyer and Sander, 2004).

b) The presence of strong osteoderms with a massive external compact and cancellous bone at its basal side.

c) The tall conical spike absent in the genus Panoplosaurus (Vickaryous et al., 2004)

The presence of these nodosaurian remains represents the southernmost report for the family (Rivera-Sylva et al., 2008; Rivera-Sylva et al., in preparation).

\subsubsection{Hadrosaurs}

Various hadrosaur specimens are known from this locality, mainly adults with an average length reaching 11 $\mathrm{m}$. The hadrosaurian nature of the vertebrae is evidenced by their platycoely and the lack of pleurocoels. The distal part of the scapular blade is squared and symmetrical with a straight dorsal margin, which is typical for Hadrosaurinae (Horner et al., 2004), probably Kritosaurus.

The fragmentary nature of the fossil record as well as the wear traces on some bones indicates decay of the carcasses upstream and subsequent and transport prior to deposition. The different age stages hint to the presence of family groups inhabiting the river or thru their migrations along its shores. River incursions or drinking episodes resulted in encounter with the crocodilians inhabiting the wetlands (Rivera-Sylva et al., 2009, in press). Evidence for theropod predation is missing for the moment.

\section{Environmental Implications of the Vertebrate Assemblage}

The vertebrate fossils found in the locality Las Jicoteas comprise both aquatic and terrestrial elements and thus lines up with other coeval localities further north (Figure 4). The presence of trionychids and lepisosteids prove evidence for a very large freshwater system with sections where low kinetic energy could be established as is the case with deep oxbows.
Trionychid turtles may occur in brackish waters but need sandy open riverbanks with shallow shores for breeding. Furthermore, both trionychids and lepisosteids mainly prey on fishes and other small vertebrates as well as a variety of invertebrates, the presence of which has to be recorded by further investigations, especially by screen washing.

Deinosuchus sp. was a large amphibious predator, which needed swampy areas with deep water areas. Nothing is known about the salt tolerance of these huge alligatorids, but they certainly occurred upstream with the option to invade the coastal region of the system. Like the trionychid turtles, Deinosuchus needed shallow beaches with sand or soil coverage for nesting. If Deinosuchus had similar breeding habits as most extant Crocodylia, the presence of at least shrubby vegetation has to be postulated for the construction of fermenter nests. Deinosuchus hatchlings, however, preferably lived in small and shallow channels or oxbow lakes in order to avoid aquatic predators like trionychids, lepisosteids, and even adult Deinosuchus. Such limnic water systems may have been the cradle for juvenile trionychids and lepisosteids as well. No matter which of the described Deinosuchus species inhabited the area, it is likely that their living conditions were those to similar to extant crocodilian habitats.

Theropoda and hadrosaurines are terrestrial elements of the assemblage. Nothing can be said about the habits of the theropods due to the scarcity of the present fossils record. One could speculate that these terrestrial predators only occasionally entered the river system, which was probably full of large crocodiles.

Cf. Kritosaurus appeared to have been the most abundant of the terrestrial mega-vertebrates. The presence of different age stages suggests that their breeding area was upstream. Being predominantly herbivorous, the hadrosaurines depended on vegetation along their trails. Due to a lack of egg shells, a nesting site in the vicinity of the locality can be ruled out.

From what is known to date, the Las Jicoteas locality was a part of the Coahuila range of the KritosaurusParasaurolophus association, which, according to Lehman (2001), belongs to the Late Campanian Judithian Climax (80 to 75 million years). This association is characterised by hadrosaurine dominating the lambeosaurine and rare Ceratopsia with Pentaceratops as a dominant taxon.

Sedimentology and depositional environment of the studied area confirm the presence of the habitat types postulated for the assemblage, or, at least are not contradictory. The freshwater system was situated on a coastal plain which drained in the Palaeogulf of Mexico. Further survey will yield more material for a detailed reconstruction of the local habitat types represented in the area, as well as the entire extent of the system within the paleogeographical context of that time period.

Recently, in an upper horizon of the same "Las Jicoteas" locality a number of large bones have been collected. From these is worth to mention a $95 \mathrm{~cm}$ long femur of a 


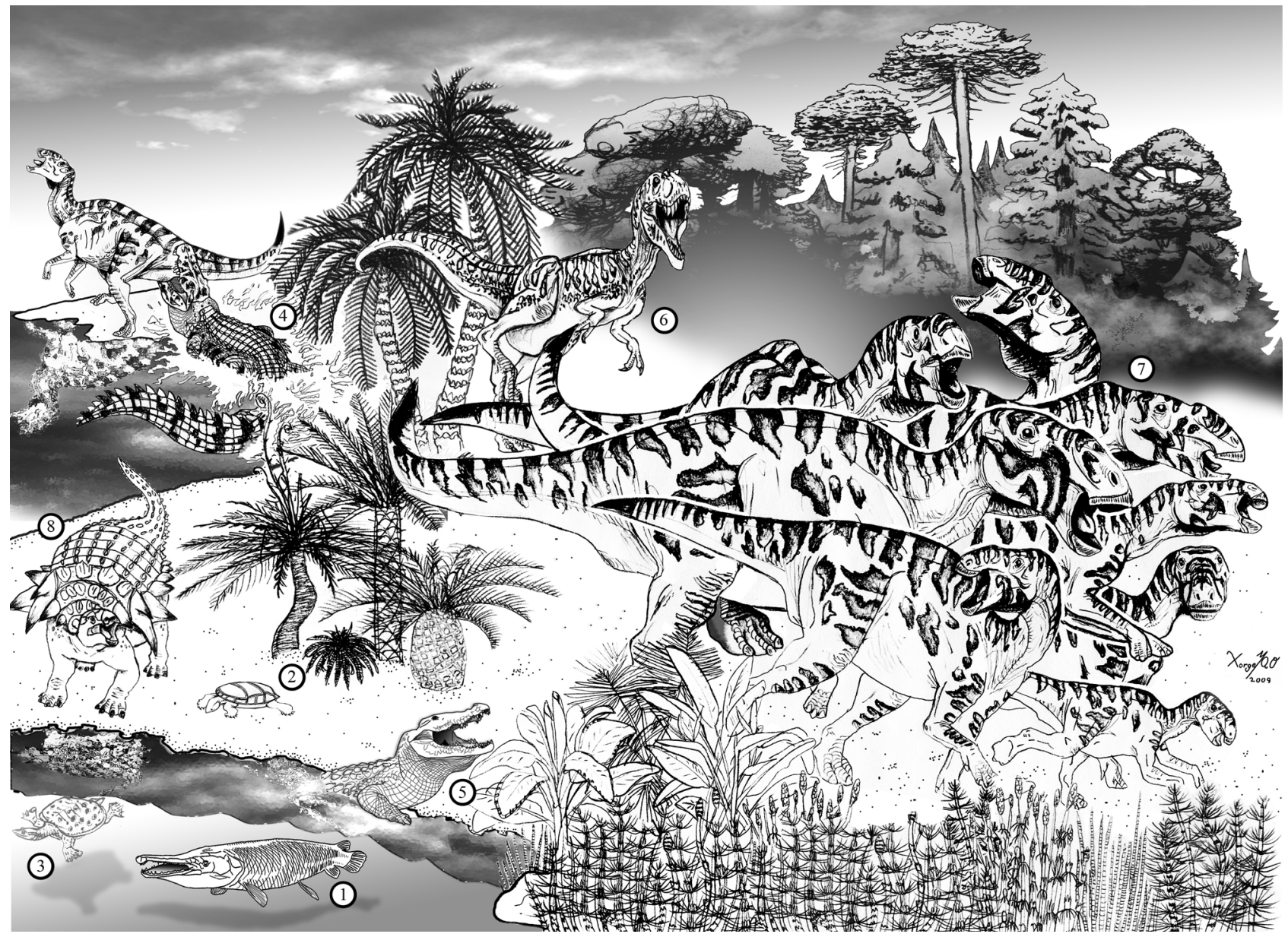

Figure 4. Palaeocological reconstruction of the Late Cretaceous Las Jicoteas locality, Aguja Formation, Coahuila. 1)Lepisosteide; 2)Baenidae; 3) Tryonichidae; 4)Deinosuchus; 5)Alligatoridae indet.; 6)Tyrannosauridae; 7) Hadrosauridae; and 8)Nodosauridae. (Ilustration by Jorge A. Ortiz Mendieta, 2009).

sauropod dinosaur. Also as the materials have been studied, no elements are duplicated and all the bones fall within a narrow size range, suggesting that they represent a single individual. Preliminary comparisons with other specimens and the reconstruction made by Lehman and Coulson (2002) indicate that these materials may belong to an adult titanosaurid, approximately 20 meters long.

The upper beds of the "Las Jicoteas" locality (an unnamed formation) seem to represent an equivalent to the Javelina Formation of the Texas Big Bend area.

\section{Acknowledgments}

We wish to thank the following individuals for their contribution to this project: José López Espinosa, Ileana de la Peña Oviedo, and Elizabeth Jardón, for their help in the field, and Leonel Guajardo for his help with the photographs, all of them affiliated to the Museo del Desierto team. The Museo del Desierto is also thanked for supporting this research. In the same manner we wish to extend our acknowledgements to Javier Francisco López Morales for his kind assistance and support to this project. Also we like to thank Tom Lehman and Luis Espinosa for their review and helpful comments that improved this manuscript. In addition we wish to thank Mr. Edgar Guzman from INEGI (now retired).

\section{References}

Abler, W.L., 1997, Tooth serrations in carnivorous dinosaurs, in Padian, K., Currie, P.J. (eds.), Encyclopedia of Dinosaurs: San Diego, Academic Press, 740-741.

Currie, P.J., 2003, Cranial anatomy of tyrannosaurids from the Late Cretaceous of Alberta: Acta Palaeontologica Polonica, 48(2), 191-226.

Currie, P.J., Rigby, Jr., J.K., Sloan, R.E., 1990, Theropod teeth from the Judith River Formation of southern Alberta, Canada, in Carpenter, K., Currie, P.J. (eds.), Dinosaur Systematics: Perspectives and Approaches: Cambridge University Press, Cambridge, 107-125.

Estes, R., 1964, Fossil vertebrates from the late Cretaceous Lance Formation, eastern Wyoming: University of California Publications in Geological Sciences, 49, 1-180. 
Farlow, J.O., Brinkmann, D.L., 1987, Serration coarseness and patterns of wear of theropod dinosaur teeth: Geological Assotiation of America, Abstracts with Programs, 19, 151.

Gaffney, E.S., 1979, Description of a large trionychid turtle from the Eocene Bridger Formation of Wyoming: Contributions to Geology, University of Wyoming, 17, 53-57.

Gardner, J.D., Russell, A.P., 1994, Carapacial variation among soft-shelled turtles (Testudines: Trionychidae) and its relevance to taxonomic and systematic studies of fossil taxa: Neues Jahrbuch für Geologie und Paläontologie, Abhandlungen, 193, 209-244.

Gardner, J.D., Russell, A.P., Brinkman, D.B., 1995, Systematics and taxonomy of soft-shelled turtles (Family Trionychidae) from the Judith River Group (mid-Campanian) of North America: Canadian Journal of Earth Science, 32, 631-643.

Haarmann, E., 1913, Geologische Streifzüge in Coahuila: Zeitschrft der Deutschen Geologischen Gesellschaft, Monatsberichte, 1, 65.

Holtz, T.R.Jr., 2004, Tyrannosauroidea, in Weishampel, D.B., Dodson, P., Osmólska, H., (eds.), The Dinosauria 2nd Edition: Berkeley, University of California Press, 111-136.

Hopkins, E.M., 1965, Sedimentology of the Aguja Formation, Big Bend National Park, Brewster County, Texas: University of Texas, Austin, M.A. Thesis.

Horner, J., Weishampel, D.B., Forster, C.A., 2004, Hadrosauridae, in Weishampel, D.B., Dodson, P., Osmólska, H. (eds.), The Dinosauria (2nd Ed.): University of California Press, Berkeley, 438-463.

Janensch, v.W., 1926, Dinosaurier-Reste aus Mexiko: Centralblatt für Mineralogie, Geologie und Paläontologie, 1926 B, 192-197.

King, P.B., 1940, Geologic Map of the Northern Part of Mexico, Plate I: United States Department of the Interior, Geological Survey.

Lehman, T.M., 1982, A ceratopsian bone bed from the Aguja Formation (Upper Cretaceous) Big Bend National Park, Texas: University of Texas, Austin, M.A. Thesis.

Lehman, T. M., 2001, Late Cretaceous Dinosaur Provinciality, in Currie, P. J., Tanke, D.H., Carpenter, K. (eds.), Mesozoic Vertebrate Life: Indiana University Press, Bloomington, 310-328.

Lehman, T. M., Coulson, A.B., 2002, A juvenile specimen of the sauropod dinosaur Alamosaurus sanjuanensis from the Upper Cretaceous of the Big Bend National Park, Texas: Journal of Vertebrate Paleontology, 76(1), 156-172.

López-Ramos, E., 1967, Carta Geológica del Estado de Coahuila, escala 1:500,000: Universidad Nacional Autónoma de México.

Montellano-Ballesteros, M., Hernández-Rivera, R., Álvarez-Reyes, G., Andrade-Ramos, P., Martín-Medrano, L., 2000, Discovery of Late Cretaceous vertebrate local faunas in norhtern Mexico: Journal of Vertebrate Paleontology, 20(3), 58-59.
Nicholls, E.L., 1972, Fossil turtles from the Campanian stage of western North America: Calgary, University of Calgary, M.A. Thesis.

Peng, J., Russell, A.P., Brinkman, D.B., 2001, Vertebrate microsite assemblages (exclusive of mammals) from the Foremost and Oldman Formations of the Judith River Group (Campanian) of southeastern Alberta: an illustrated guide: The Provincial Museum of Alberta, Natural History Occasional Paper, 24, 1-54.

Rivera Sylva, H.E., López-Espinoza, J., 2006, Reporte preliminar de una nueva localidad fosilífera del Cretácico Tardío en Coahuila, México (resumen), en X Congreso Nacional de Paleontología: Ciudad de México, México, Sociedad Mexicana de Paleontología, 10, 130.

Rivera-Sylva, H.E., Guzmán-Gutiérrez, J.R., Palomino-Sánchez, F.R., 2006, Preliminary report on a vertebrate fossil assamblage from the Late Cretaceous of Chihuahua, Mexico, Hantkeniana, 5, 66-68.

Rivera Sylva, H.E., Guzmán-Gutiérrez, R., Palomino-Sánchez, F., LópezEspinosa, J., de la Peña Oviedo, I., 2007, New Vertebrate Fossil Locality from the Late Cretaceous of Northern Coahuila, México: Journal of Vertebrate Paleontology, 27(Suppl. 3), 135A.

Rivera Sylva, H.E., Guzmán-Gutiérrez, R., Palomino-Sánchez, F., LópezEspinosa, J., de la Peña Oviedo, I., 2008, First Report of the Genus Edmontonia (Thyreophora: Nodosauridae) from Mexico: Journal of Vertebrate Paleontology, 28(Suppl. 3), 132A.

Rivera-Sylva, H.E., Guzmán-Gutiérrez, R., Frey, E., 2009, Evidence of predation on the vertebra of a hadrosaurid dinosaur from the Late Cretaceous (Campanian) of Coahuila, Mexico. Carnets de Geologié, (In press)

Sankey, J.T., 2001, Late Campanian Souther Dinosaurs, Aguja Formation, Big Bend, Texas: Journal of Paleontology, 75(1), 208-215.

Scheyer, T.M., Sander, P.M., 2004, Histology of Ankylosaur osteoderms: implications for systematic and function: Journal of Vertebrate Paleontology, 24(4), 874-893.

Schwimmer, D.R., 2002, King of the Crocodylians: The Paleobiology of Deinosuchus: Indiana University Press, Bloomington. 220 pp.

Vickaryous, M.K., Maryańska, T., Weishampel, D.B., 2004, Ankylosauria, In: Weishampel, D.B., Dodson, P., Osmólska, H. (eds.), The Dinosauria, 2nd Edition: Berkeley, University of California Press, Berkeley, 363-392.

Manuscript received: February 27, 2009

Corrected manuscript received: June 22, 2009.

Manuscript accepted: June 29, 2009. 